Mass Media, Politics and Democracy 


\section{By the same author}

\section{Politics and Popular Culture}

Rebel Rock: the politics of popular music

Politics and Technology

Deciding Factors in British Politics (with John Greenaway and Steve Smith) 


\title{
Mass Media, Politics and Democracy
}

\author{
John Street
}




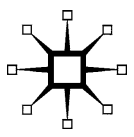

(C) John Street 2001

All rights reserved. No reproduction, copy or transmission of this publication may be made without written permission.

No paragraph of this publication may be reproduced, copied or transmitted save with written permission or in accordance with the provisions of the Copyright, Designs and Patents Act 1988, or under the terms of any licence permitting limited copying issued by the Copyright Licencing Agency, 90 Tottenham Court Road, London W1P 0LP.

Any person who does any unauthorized act in relation to this publication may be liable to criminal prosecution and civil claims for damages.

The author has asserted his right to be identified as the author of this work in accordance with the Copyright, Designs and Patents Act 1988.

First published in 2001 by

PALGRAVE

Houndmills, Basingstoke, Hampshire, RG21 6XS and

175 Fifth Avenue, New York, N.Y. 10010

Companies and representatives throughout the world

PALGRAVE is the new global academic imprint of St. Martin's Press LLC Scholarly and Reference Division and Palgrave Publishers Ltd (formerly Macmillan Press Ltd).

ISBN 978-0-333-69304-9 hardback

ISBN 978-0-333-69305-6 ISBN 978-1-4039-4009-4 (eBook)

DOI 10.1007/978-1-4039-4009-4

This book is printed on paper suitable for recycling and made from fully managed and sustained forest sources.

A catalogue record for this book is available from the British Library.

Library of Congress Cataloging-in-Publication Data

Street, John, 1952-

Mass Media, politics, and democracy/John Street p. cm.

Includes bibliographical references and index.

ISBN 978-0-333-69304-9 - ISBN 978-0-333-69305-6 (pbk.)

1. Mass media-Political aspects. 2. Democracy 1. Title.

P95.8 .S77 2001

302.23-dc21

2001021274

$\begin{array}{rrrrrrrrrr}10 & 9 & 8 & 7 & 6 & 5 & 4 & 3 & 2 & 1 \\ 10 & 09 & 08 & 07 & 06 & 05 & 04 & 03 & 02 & 01\end{array}$

Copy-edited and typeset by Povey-Edmondson,

Tavistock and Rochdale, England 
To Marian, Alex, Jack and Tom 


\section{Contents}

Acknowledgements ix

$\begin{array}{ll}\text { Introduction } & 1\end{array}$

PART ONE REPRESENTING POLITICS

1. Political bias $\quad 15$

2. Telling tales: the reporting of politics 36

3. It's just for fun: politics and entertainment 60

4. Media effects $\quad 80$

PART TWO THE POLITICAL ECONOMY OF MASS MEDIA

5. State control and state propaganda 103

6. Conglomerate control: media moguls and media power 124

7. Watchdogs or lapdogs? The politics of journalism 145

8. Dream worlds: globalization and the webs of power 163

PART THREE MASS MEDIA AND DEMOCRACY

9. Packaging politics 185

10. Remote control 212

11. Power and mass media 231

12. A free press: democracy and mass media 250

$\begin{array}{ll}\text { Conclusion } & 273\end{array}$

$\begin{array}{ll}\text { Bibliography } & 278\end{array}$

$\begin{array}{ll}\text { Index } & 294\end{array}$ 


\section{Acknowledgements}

My thanks to a variety of people who have, sometimes unwittingly, contributed to this book: Sigrid Baringhorst, Michael Billig, Marian Brandon, John Corner, Ian Forbes, Marion Forsyth, Steve Foster, Simon Frith, Peter Golding, Andy Grantham, John Greenaway, Brian Loader, Lee Marsden, Anne Martin, Carla Moore, Kate Nash, Keith Negus, Pippa Norris, Keith Povey, Alex Rousso, Roberta Sassatelli, Alan Scott, David Sinclair, Steve Smith, Mike Stephens, Hazel Taylor, Liesbet Van Zoonen, Frank Webster, several anonymous reviewers and many generations of students at the University of East Anglia. I owe a particular debt to my publisher Steven Kennedy who has been unfailingly helpful and encouraging, and who has showed a degree of patience that I have done little to deserve. I hope the wait has been worthwhile. My family - Marian, Alex, Jack and Tom - have also had to live with this book for a long time. It is dedicated to them.

\section{JoHn STREET}

This book draws in places on some earlier articles by the author: 'In Praise of Packaging', Harvard International Journal of Press/Politics, 1(2), 1996, 43-55; 'Remote Control? Politics, Technology and "Electronic Democracy", European Journal of Communication, 12(1), 1997, 27-42; 'Prime Time Politics: Popular Culture and Politicians in the UK', The Public/Javnost, 7(2), 2000, 75-90; and (with Alan Scott) 'From Media Politics to e-protest: The Use of Popular Culture and New Media in Parties and Social Movements', Information, Communication and Society, 3(2), 2000, 215-40. 